Ege Tıp Dergisi / Ege Journal of Medicine 2017;56(2):86-87

\title{
Çocukluk çağı miyastenia gravis
}

Myasthenia gravis at childhood

İhsan Çakır Osman Bulut Ocak Aslı Inal Ebru Demet Aygıt Birsen Gökyiğit

Gamze Öztürk Karabulut

Prof.Dr. N. Reşat Belger Beyoğlu Göz Eğitim ve Araştırma Hastanesi, Göz Hastalıkları Kliniği,

İstanbul, Türkiye

\section{Öz}

Jüvenil miyastenia gravis (JMG) çocukları etkileyen en yaygın miyastenik hastalıktır. JMG nöromüsküler kavşak proteinlerini hedef alan bir grup otoimmün antikor kaynakı hastalığı içerir. Hastalığın klinik belirtisi dinlenmekle azalan istemli kaslarda yorgunluk ve güçsüzlüktür. Ptozis, oftalmopleji ve bunlara eşlik eden diplopi hastalığın ilk belirtisi olabilmektedir. Bu yazıda, dış merkezlerde strabismus sebebiyle operasyon önerilen bir JMG olgusu sunulmaktadır.

Anahtar Sözcükler: Jüvenil miyastenia gravis, ptozis, strabismus, oftalmopleji.

\begin{abstract}
Juvenile myasthenia gravis (JMG) is the most common myasthenic disorder affecting children. JMG includes a group of autoimmune antibody-mediated disorders targeting neuromuscular junction proteins. The clinical hallmark of the disease is fluctuating and fatigable skeletal muscle weakness, which improves with rest. Ocular symptoms could be the first signs of the disease as ptosis, ophthalmoplegia, and/or diplopia. In this study we present a JMG patient who was planned to be operated for strabismus before referring to our clinic.
\end{abstract}

Keywords: Juvenile myasthenia gravis, ptosis, strabismus, ophthalmoplegia.

\section{Giriş}

Miyastenia gravis (MG), nöromusküler bileşkenin antikorlar tarafından hasarlandığı kompleks bir hastalıktır. Bu hastalıkta klinik olarak vücudun istemli kasları özellikle göz, ağız, göğüs ve ekstremite kasları etkilenir (1). Çocukluk çağında ortaya çıkan MG, jüvenil miyastenia gravis (JMG) olarak adlandırıır ve tüm MG hastalarının yaklaşık \%10'unu oluşturur (2). JMG tanısı almış hastalarda, başlangıç semptomlarının sıklıkla ekstraoküler kas tutulumuna bağlı olarak ptozis, diplopi ve strabismus olduğu bildirilmektedir (3). Bu makalede strabismus sebebiyle başvurdukları dış merkezlerde cerrahi müdahale önerilmesi üzerine hastanemizin şaşılık birimine başvuran ve tarafımızca pediatrik nöroloji bilim dalına yönlendirilerek JMG tanısı konulan olgunun sunumu amaçlanmıştır.

\section{Olgu Sunumu}

Ailesi tarafından 2014 yılında kliniğimize getirilen 8 yaşındaki kız olgunun geliş şikayetleri az görme ve sol gözde içe kayma idi.

\footnotetext{
Yazışma Adresi: Osman Bulut Ocak

Prof.Dr. N. Reşat Belger Beyoğlu Göz Eğitim ve Araştırma Hastanesi, Göz Hastalıkları Kliniği, İstanbul, Türkiye

Makalenin Geliş Tarihi: 09.03.2016 Kabul Tarihi: 26.05.2016
}

Hastanın öyküsünde 4 yaşından beri farklı kliniklerde düzensiz bir şekilde takip edildiği, görme azlığı için kapama tedavisi verildiği ve şaşılık için operasyon önerildiği öğrenildi. Öz ve soy geçmişinde bir özellik bulunmadı. Yapılan oftalmolojik muayenesinde, en iyi düzeltilmiş görme keskinlikleri sağ gözde (-4.25 -1.00 a 145) tashihle 0.5 , sol gözde (-2.00 -1.50 a 160) tashihle 0.1 idi. Ön segment ve arka segment muayeneleri doğal bulundu. Şaşılık muayenesinde örtme açma testi ile alterne olmayan sol ezotropya (ET) görüldü. Yapılan prizma kapama testi (PKT) ile yakında 18 prizma diyoptrisi (PD) ET, uzakta 18 PD ET bulundu. Göz hareketlerinde her iki göz dışa bakışta hafif kısıtııık saptandı. Yapılan sikloplejinli refraksiyon muayenesinde; sağ göz (-3,75 -0.75 a 144), sol göz (-1,50 -2,25 a 154) bulundu. Stereopsis 400 saniye/ark (sn/ark) olarak saptandı (Şekil-1a). Olgunun muayenesi sırasında ailesi, olgunun göz kayması şikayetinin özellikle yatarken belirgin biçimde arttığını ve sabah kaymasının kalmadığını belirtti. Bunun üzerine olgunun ailesinden aydınlatılmış onam alınarak JMG ön tanısı ile pediatrik nöroloji bilim dalından konsültasyon istendi ve en iyi gördüğü tashihli gözlük verilerek sağ göze 2 saat/gün kapama başlandı. Olguya pediatrik nöroloji tarafından tekrarlayan sinir uyarımı ve orbikularis oküli kasında tek 
lif elektromiyelografi (EMG) ve antikolinerjik tedaviye olumlu yanıt alınması ile JMG tanısı kondu ve pridostigmin $60 \mathrm{mg}$ tablet $3 \times 1$ başlandı.

Medikal tedavi ve kapama tedavisi sonrası 3. ayında hastanın en iyi düzeltilmiş görme keskinlikleri sağ gözde 0.7 , sol gözde 0.6 olarak saptandı. PKT ile yakında 8 PD ET, uzakta 6 PD ET saptanan hastada göz hareketleri her yöne serbest idi (Şekil-1b).

Hastanın yasal vasisinden tıbbi verilerinin yayınlanabileceğine ilişkin yazılı onam belgesi alındı.

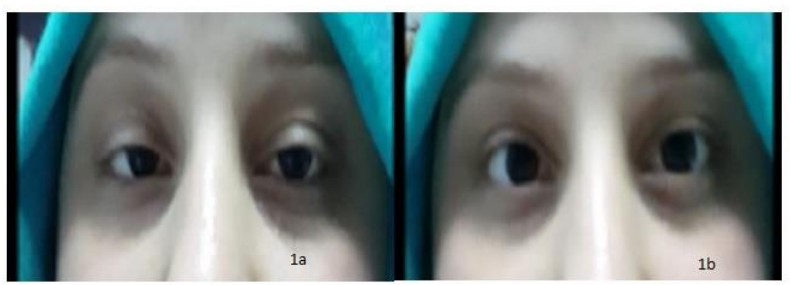

Şekil-1. a.Başvuru sırasında saptanan 18 PD sağ ezotropya b. 3 aylık medikal tedavi sonrası görünüm

\section{Tartışma}

MG nöromüsküler bileşkenin bir hastalığıdır. Genellikle ikinci ve üçüncü dekadda başlamakta olup çocuklarda daha nadir görülmektedir (1). Bebeklik ve çocukluk çağında geçici neonatal, konjenital ve JMG olarak 3 formda görülebilen çocukluk çağı MG'de en sık görülen form JMG'dir $(2,4)$. Literatürde, Kim ve ark. (5) semptomların başlangıç yaşını ortalama 38 ay olarak bulmuşlardır. Mullaney ve ark. (6) ise semptomların ortalama başlangıç yaşını 78 ay olarak belirtmişlerdir. Olgumuzun tahmini başlangıç yaşı 50 aydır.
JMG'de sistemik tutulum oranı \%3-\%35 arasında olup, $\% 47$ oranında sadece ekstraoküler kaslar tutulmaktadır $(3,7)$. JMG'de ilk bulgular ise genellikle ekstraoküler bulgular olup, buna bağlı olarak hastaların çoğu ilk olarak göz kliniklerine başvurmaktadırlar $(5,6)$. JMG olgularında konkomitan ve inkomitan strabismus ve göz hareketlerinde kısıtlılık görülebilmektedir $(5,6)$. Olgumuzda da hastanın geliş şikayeti gözlerde kaymaydı ve göz hareketlerinde kısıtlılık bulunmaktaydı. JMG'de ptozis ve strabismusa sekonder olarak ambliyopi gelişebilir $(5,8)$. Ellenhorn ve ark. (8) 26 ve 36 aylık iki hastada yaptıkları çalışmada JMG'den kaynaklanan ptozis ve strabismusa sekonder ambliyopi tespit etmişlerdir. Kim ve ark. (5) olguların \% 21'inde ambliyopi saptamışlardır. Olgumuzda ambliyopi tespit edilmiş ve tedavisine başlanmıştır. Tanıda, EMG'de tekrarlayıcı uyarımda \%10'u geçen dekrement yanıtı ya da tek lif EMG'de uzamış jitter şeklinde elektrofizyolojik anormalliğin bulunması, antikolinerjik ilaçlara klinik yanıt alınması, serolojik testlerde asetilkolin reseptör antikorlarının pozitifliğinin gösterilmesinden faydalanılır (9). Olgumuzda da EMG bulguları ve antikolinerjik tedaviye olumlu yanıt alınması ile tanı konmuştur. Tedavide oral antikolinesteraz, kortikosteroidler ve bazen azatioprin, siklosporin gibi immünsüpresifler kullanılmaktadır $(7,10)$. Olgumuzda antikolinesteraz tedavisi sonrası semptomlar gerilemiş veya kaybolmuştur.

Sonuç olarak JMG olgularının bir kısmı ilk olarak göz kliniklerine başvurmaktadır. Hastanın şikayetlerinin gün içerisinde değişiklik göstermesi ve kontrol muayenelerinde bulgulardaki farklılıkların göze çarpması durumunda JMG akılda bulundurulmalıdır.

\section{Kaynaklar}

1. Sarnat HB. Disorders of neuromuscular transmission and of motor neurons. In: Kliegman RM, Behrman RE, Jenson HB, Stanton FB (eds). Nelson Textbook of Pediatrics. $18^{\text {th }}$ ed. Philadelphia: Saunders Elsevier; 2007:2554-2559.

2. Değerliyurt A, Şenbil N, Anlar B. Jüvenil (otoimmün) miyasteni: Klinik özellikler ve tedavi sonuçları. Çocuk Sağlığı ve Hastalıkları Dergisi 2005;48(1):25-29.

3. Evoli A, Batocchi AP, Bartoccioni E, Lino MM, Minisci C, Tonali P. Juvenile myasthenia gravis with prepubertal onset. Neuromuscular Disorders 1998;8(8):561-7.

4. Saltık S, Ergüven M, Turgut T, Demirbilek V, Özümüztoprak N, Doğu A. Çocukluk çağında miyastenia gravis. Türk Pediatri Arşivi 2004;39:135-8.

5. Kim JH, Hwang JM, Hwang YS, Kim KJ, Chae J. Childhood ocular myasthenia gravis. Ophtalmology 2003;110(7):1458-62.

6. Mullaney P, Vajsar J, Smith R, Buncic JR. The natural history and ophthalmic involvement in childhood myasthenia gravis at the hospital for sick children. Ophthalmology 2000;107(3):504-10.

7. Batocchi AP, Evoli A, Palmisani MT, Lo Monaco M, Bartoccioni M, Tonali P. Early onset myasthenia gravis: Clinical characteristics and response to therapy. Eur J Pediatr 1990;150(1):66-8.

8. Ellenhorn N, Lucchese N, Greenwald M. Juvenile myasthenia gravis and amblyopia. Am J Ophthalmol 1986;101(2):214-7.

9. Tanrısever Ö, Sarıoğlu B, Kanık A, Arslan CN, Baydan F. Farklı bir klinik başlangıç gösteren miyastenia gravis olgusu. Tepecik Eğit Hast Derg 2014;24(1):59-62.

10. Yılmaz Ü, Yiş U. Jüvenil miyastenia gravis: Üç olgu sunumu ve literatürün gözden geçirilmesi. J Clin Anal Med 2015;6(4):473-8. 